\title{
THE EFFECTS OF NATURAL SELECTION ON BODY COLOUR IN THE LAND SNAIL CEPAEA NEMORALIS
}

\author{
A. J. CAIN AND P. M. SHEPPARD \\ Department of Zoology and Comparative Anatomy, \\ University of Oxford
}

Received 21.xi.51

\section{INTRODUCTION}

Ir has been shown in earlier papers (Cain and Sheppard, I950; Sheppard, 195I) that, contrary to the opinion of other workers, variation in the colour and banding patterns of the very polymorphic land snail Cepaea nemoralis (L.) is not random. It is controlled by natural selection. Two main types of selection are acting; one is physiological, producing here a condition of stable polymorphism, and the other predatory, determining the actual ratio of phenotypes in each colony according to the aspect of the background on which it lives. Lamotte (I950) has also shown, independently, that predatory selection by thrushes results in a differential elimination of banding-patterns.

In the course of our earlier work it was noticed that there appeared to be a correlation between the darkness of the background and the shade of body colour of the snails living on it. This paper describes an investigation of this correlation. It is found that here again variation. is dominated by natural selection and is not random.

\section{METHODS}

Sampling.-Random samples were taken from nineteen collecting stations, nine of which were from different parts of the same colony. At each station, all the living adult snails seen were taken.

Localities.-The collecting stations were chosen so that the samples were drawn from different types of background. These were as follows:

Rockley Colony (Wiltshire) :

Station I. Beechwood with some green herbage.

2. Dense beechwood.

3. Beechwood with grass.

4. Open downland adjacent to beechwood.

5. Open downland 50 yards away from beechwood.

6. Beech hedge (neglected and very dense, principally with bare earth and drifts of beech leaves beneath it).

7. Open downland.

8. Beech copse, dense.

9. Beechwood, moderately open, but with little green vegetation.

Ashbury (Berkshire): Dense beechwood.

Rough Down (Wiltshire): Open downland.

Sheepstead Hurst (Berkshire): Rough green herbage (meadowsweet, comfrey, willowherb, nettles, etc.).

217 
Frilford (Berkshire): As Sheepstead Hurst.

Hinksey Hill (Berkshire): As Sheepstead Hurst.

Cumnor Hill (foot) (Berkshire): Rough green herbage (principally garden weeds).

Stretham (Cambridgeshire): Hedgerow with much grass.

Botley hedge (Berkshire): Hedgrow with green herbage.

Wytham Lane (Berkshire): Hedgerow with green herbage.

Marley Wood (Berkshire): Open mixed deciduous wood with much light brown leaf litter.

Earlier collections from Rough Down, and Rockley $\mathrm{I}, 2$ and 3 combined, were reported on by Cain and Sheppard (1950).

Scoring.--The shell colours and banding patterns were classified on the system already described by Cain and Sheppard (1950).

The body colour in C. nemoralis is predominantly some shade of grey, deepening to black in some individuals, and almost absent in others. In certain individuals there is a tinge of yellow throughout, and in a few a suffusion of a reddish-chocolate colour. It was found possible to ignore these tinges and match each animal against the series of $2 \mathrm{I}$ neutral shades given at the left-hand edge of each plate in the colour atlas of Villalobos (1947), which ranges from black (o) to white (20).

As the shade is not uniform over the body of each snail, the forehead was chosen for matching, because it gives a good indication of the general body shade. All scoring was done with individuals as nearly as possible fully expanded, since the shade varies with the degree of expansion, especially in the lightest individuals.

Pigment.-The cytological basis of the body shade was investigated with material fixed in formal-calcium (Baker, 1944) and sectioned on the freezing microtome, gelatine-embedding being unnecessary. The histochemical methods used are given by Lison (1936).

Environmental effects.-A number of snails, mostly immature, were kept together in the same container on the same diet for some months (3o May to 8 Sep. I95I) and were scored for body shade at intervals, in order to determine how far differences in body shade could be ascribed to environmental influences. The container was a wooden tub covered with a sheet of glass, and one-quarter filled with damp earth and turf. It was placed in an unheated shed. The humidity in it was high at all times. Lighting was diffuse daylight from a nearby window; its intensity at the bottom of the tub was at most as high as in a dense beechwood at the same time of day. The food used was lettuce, and corn-flakes put out on damp filter-paper which was also eaten.

\section{RESULTS}

The results of scoring for colour of shell, banding of shell, and shade of body are given for each collecting station in tables $1-3$. The correlations between the percentage of yellow shells and greenness of the background, and between the percentage of effectively unbanded shells and uniformity of the background which were shown previously (Cain and Sheppard, 1950) hold good for these samples of which all but four are from new localities. 
TABLE I

Relation between phenotypes of shell and body shade

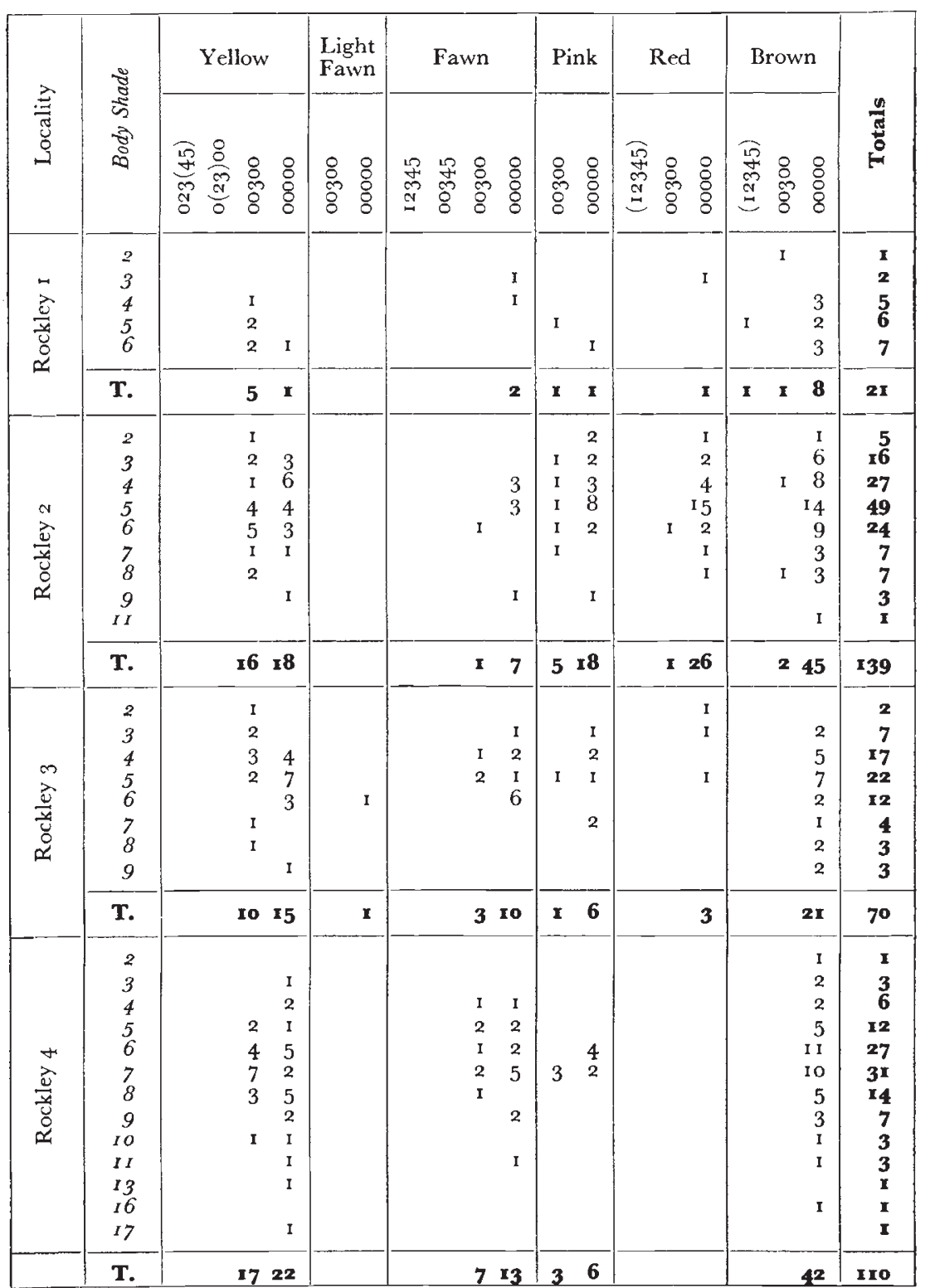


TABLE I-continued.

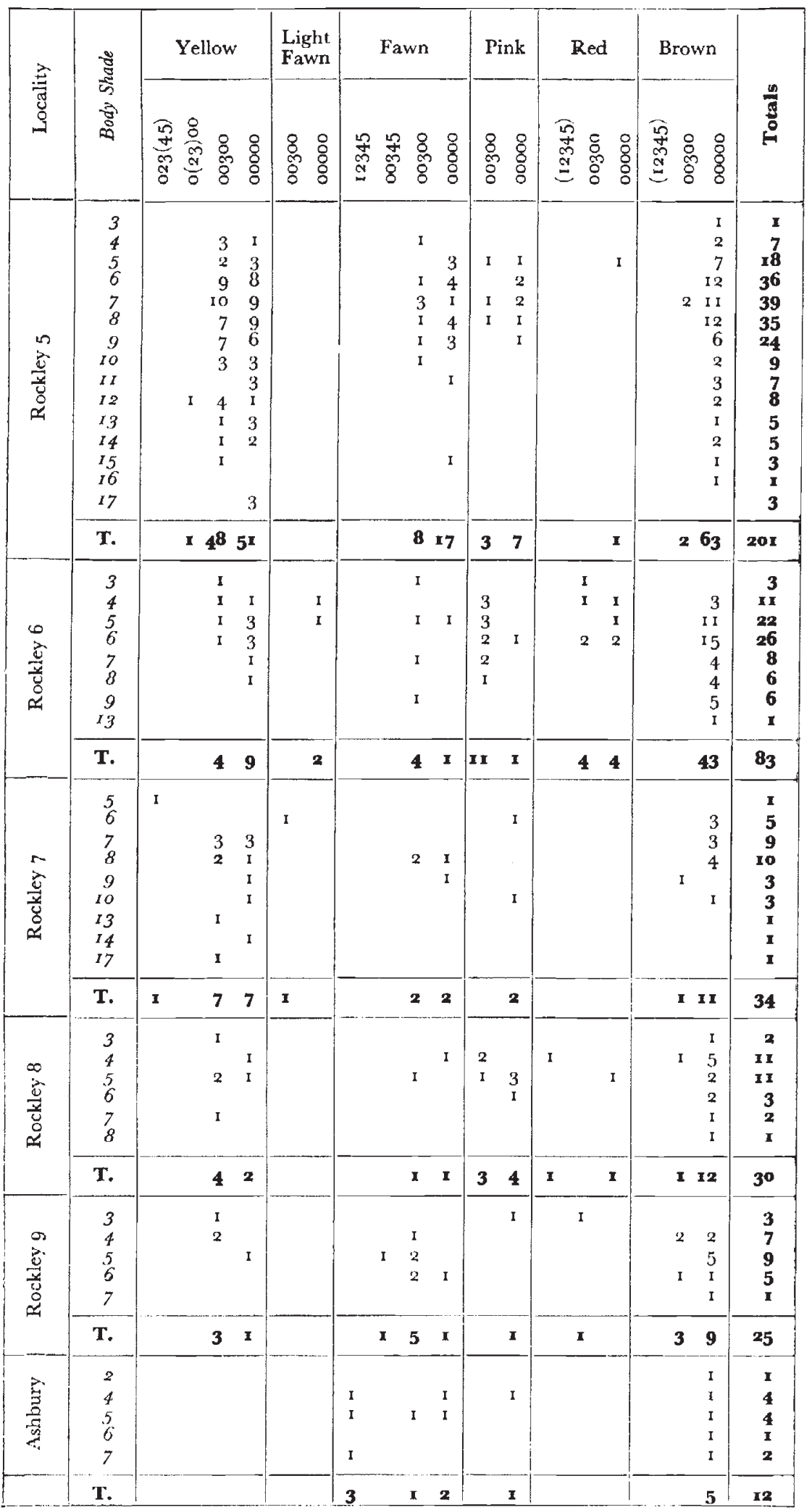


TABLE 2

Relation between phenotypes of shell and body shade

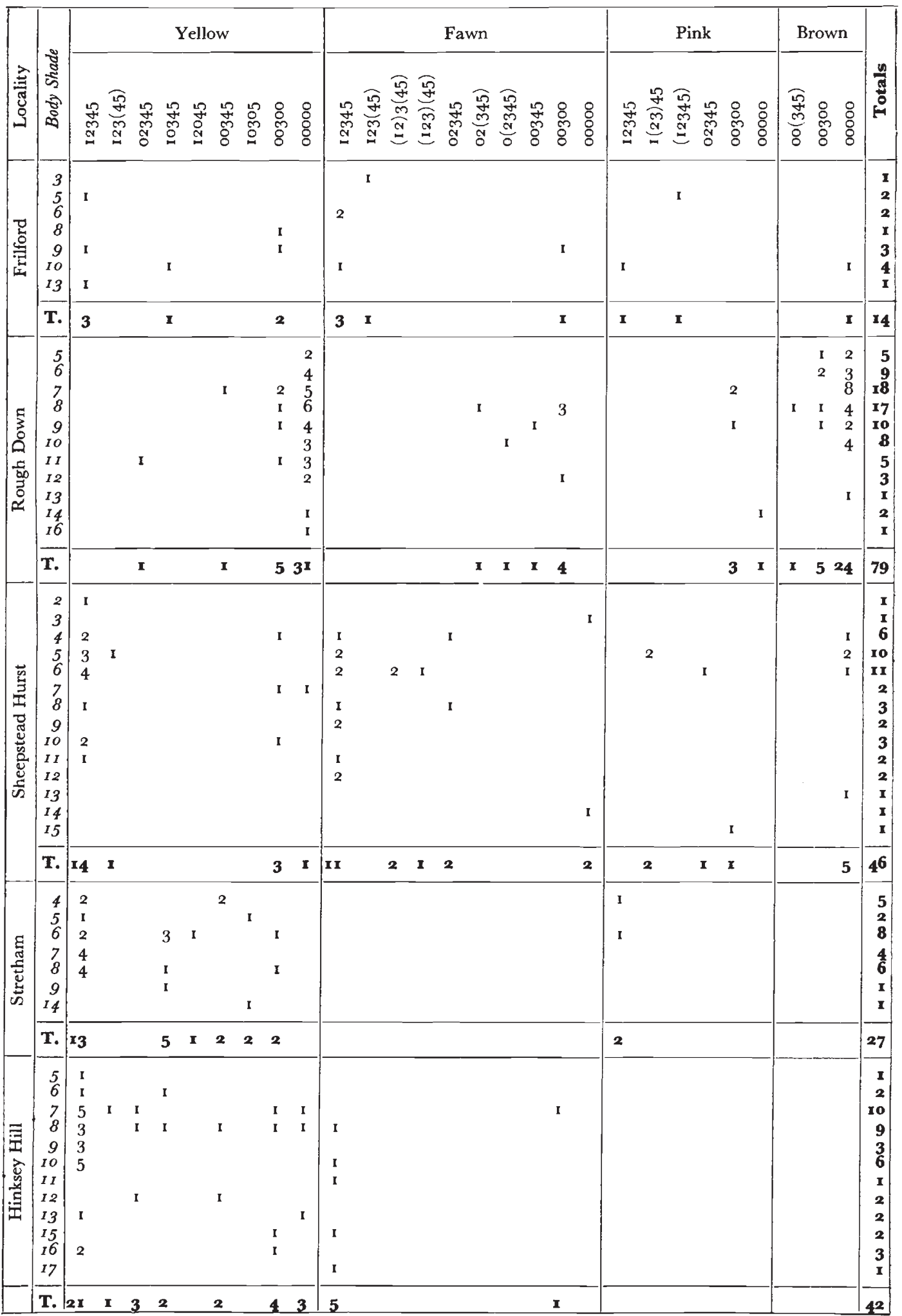


TABLE 3

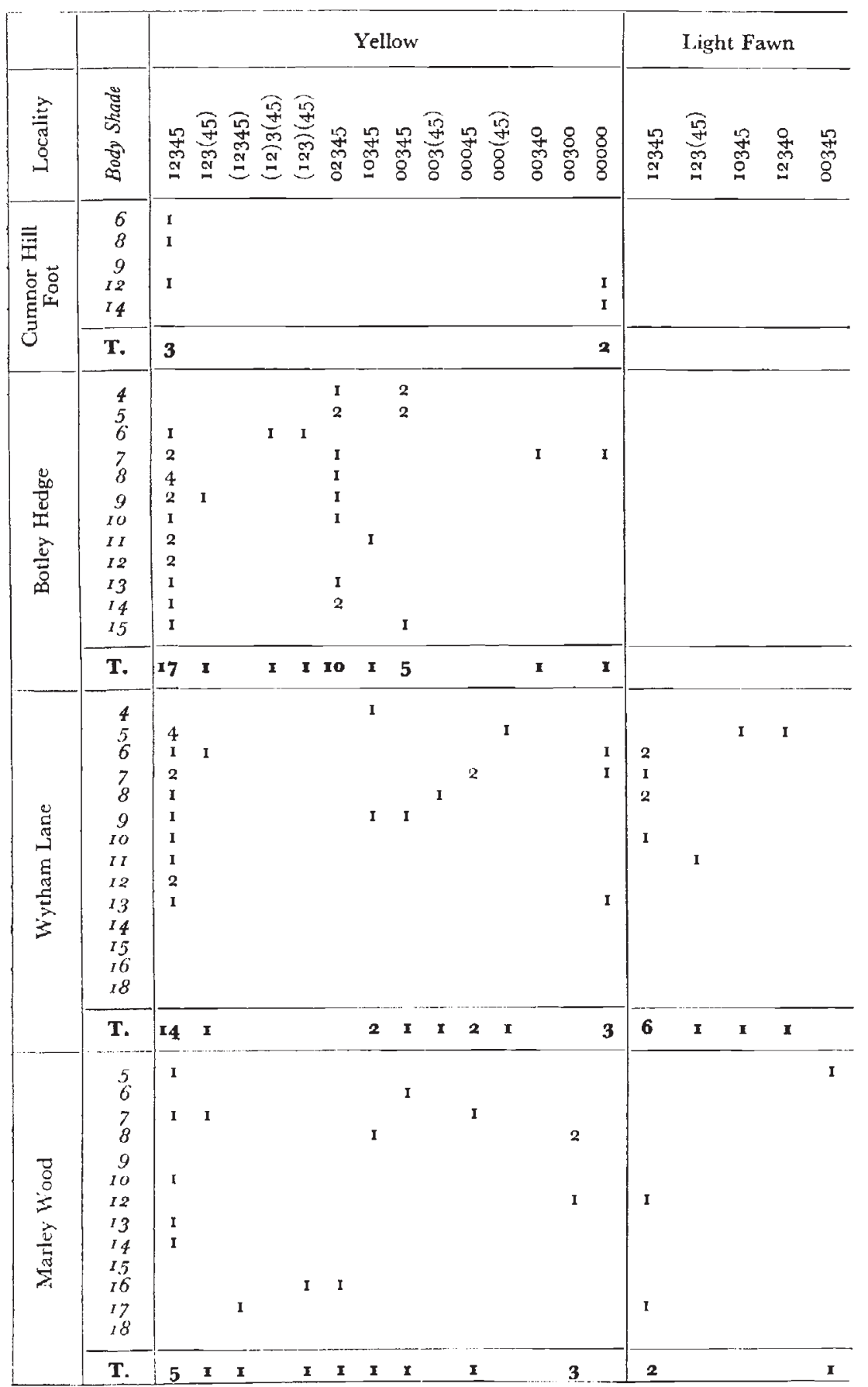


Relation between phenotypes of shell and body shade

\begin{tabular}{|c|c|c|c|c|c|c|c|c|c|c|c|c|c|c|c|c|c|c|}
\hline & & \multicolumn{10}{|c|}{ Fawn } & \multicolumn{5}{|c|}{ Pink } & \multicolumn{2}{|c|}{ 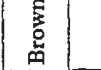 } \\
\hline 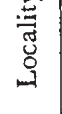 & 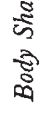 & 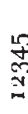 & $\frac{\widehat{a}}{\mathrm{~g}}$ & 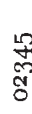 & $\frac{\pi}{5}$ & & 导 & ‡్ & $\begin{array}{l}\text { ? } \\
8 \\
8\end{array}$ & $\stackrel{8}{\circ}$ & : & 号 & 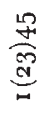 & 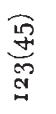 & $\frac{\sqrt[3]{9}}{\stackrel{9}{d}}$ & $\begin{array}{l}\text { : } \\
:\end{array}$ & 8 & 曾 \\
\hline \multirow[t]{2}{*}{ 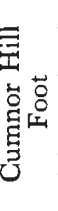 } & $\begin{array}{r}6 \\
8 \\
9 \\
12 \\
14 \\
\end{array}$ & 2 & & & & & & & & & & & & & & & & $\begin{array}{l}x \\
x \\
2 \\
2 \\
x\end{array}$ \\
\hline & T. & 2 & & & & & & & & & & & & & & & & 7 \\
\hline \multirow[t]{2}{*}{ 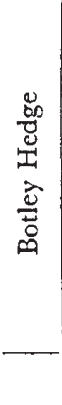 } & $\begin{array}{r}4 \\
5 \\
6 \\
7 \\
8 \\
9 \\
10 \\
11 \\
12 \\
13 \\
14 \\
15\end{array}$ & $\begin{array}{l}\text { I } \\
\text { I } \\
\text { I }\end{array}$ & & & & & & & & & & & & & & & $\begin{array}{l}2 \\
3 \\
2 \\
1 \\
2 \\
1 \\
1 \\
2 \\
2 \\
1\end{array}$ & $\begin{array}{l}5 \\
5 \\
4 \\
9 \\
7 \\
5 \\
4 \\
3 \\
3 \\
4 \\
5 \\
3\end{array}$ \\
\hline & T. & 4 & & & & & & & & & & & & & & & 15 & 57 \\
\hline \multirow[t]{2}{*}{ 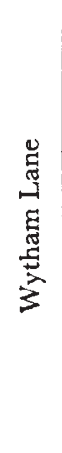 } & $\begin{array}{r}4 \\
5 \\
6 \\
7 \\
8 \\
9 \\
10 \\
11 \\
12 \\
13 \\
14 \\
15 \\
16 \\
18\end{array}$ & $\begin{array}{l}\text { I } \\
\text { I } \\
\text { I }\end{array}$ & & & & & I & & $\begin{array}{l}\text { I } \\
\text { I }\end{array}$ & & & & & & & & $\begin{array}{l}\text { I } \\
2 \\
\text { I } \\
\text { I } \\
2 \\
\text { I } \\
\text { I } \\
\text { I }\end{array}$ & $\begin{array}{r}1 \\
7 \\
8 \\
11 \\
5 \\
4 \\
3 \\
2 \\
2 \\
4 \\
3 \\
1 \\
1 \\
1\end{array}$ \\
\hline & T. & 5 & & & & & $\mathbf{I}$ & & 2 & & & & & & & & XI & 53 \\
\hline \multirow[t]{2}{*}{ 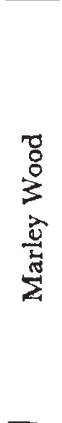 } & $\begin{array}{r}5 \\
6 \\
7 \\
8 \\
9 \\
10 \\
12 \\
13 \\
14 \\
15 \\
16 \\
17 \\
18\end{array}$ & 3 & 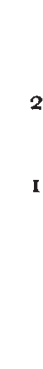 & I & & I & & I & & I & $\begin{array}{l}\text { I } \\
\text { I }\end{array}$ & I & I & I & I & I & I & $\begin{array}{l}3 \\
3 \\
8 \\
5 \\
4 \\
5 \\
4 \\
4 \\
2 \\
2 \\
3 \\
2 \\
1\end{array}$ \\
\hline & T. & IO & 3 & $=$ & 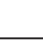 & $x$ & & $\mathbf{I}$ & & 2 & 2 & $\mathbf{I}$ & I & $\mathbf{I}$ & $I$ & $\mathbf{I}$ & 2 & $4^{6}$ \\
\hline
\end{tabular}


TABLE 4

Dependence of body shade on age and environment (I95I)

\begin{tabular}{|c|c|c|c|c|c|c|c|}
\hline \multirow{2}{*}{\multicolumn{2}{|c|}{$\begin{array}{c}\text { Phenotype of indi- } \\
\text { vidual shell in order } \\
\text { of increasing light- } \\
\text { ness of body }\end{array}$}} & \multicolumn{6}{|c|}{ Body Shade } \\
\hline & & 3o May & I 5 June & I 9 July & 7 Aug. & 24 Aug. & 8 Sept. \\
\hline $\begin{array}{l}\text { Yellow } \\
\text { Pink }\end{array}$ & $\begin{array}{l}\text { 0oooo } \\
\text { oozoo } \\
\text { 00000 }\end{array}$ & $\begin{array}{l}4^{3} \\
4^{2} \\
4^{3}\end{array}$ & $\begin{array}{l}5^{3} \\
4^{2} \\
5^{3}\end{array}$ & $\begin{array}{l}6^{4} \\
4^{3} \\
5^{4}\end{array}$ & $\begin{array}{l}5^{4} \\
5^{4} \\
5^{4}\end{array}$ & $\begin{array}{l}5^{4} \\
4^{4} \\
4^{4}\end{array}$ & $\begin{array}{l}5^{4} \\
5^{4} \\
4^{4}\end{array}$ \\
\hline $\begin{array}{l}\text { Yellow } \\
\text {," } \\
\text { Pink } \\
\text { Brown } \\
\text {," } \\
\text { ", } \\
\text {," }\end{array}$ & $\begin{array}{c}\text {," } \\
\text { 0o30o } \\
\text { ooooo } \\
, " \\
, " \\
\text { ", }\end{array}$ & $\begin{array}{l}5^{3} \\
- \\
5^{3} \\
5^{3} \\
5^{3} \\
5^{3}\end{array}$ & $\begin{array}{l}7^{3} \\
5^{2} \\
5^{2} \\
5^{3} \\
5^{3} \\
5^{3} \\
4^{3}\end{array}$ & $\begin{array}{l}4^{4} \\
5^{3} \\
6^{2} \\
5^{4} \\
4^{3} \\
6^{4} \\
5^{4}\end{array}$ & $\begin{array}{l}5^{4} \\
6^{4} \\
5^{2} \\
5^{4} \\
4^{4} \\
6^{4} \\
5^{4}\end{array}$ & $\begin{array}{l}4^{4} \\
6^{4} \\
5^{2} \\
4^{4} \\
5^{4} \\
5^{4} \\
6^{4}\end{array}$ & $\begin{array}{l}4^{4} \\
5^{4} \\
5^{3} \\
3^{4} \\
4^{4} \\
5^{4} \\
5^{4}\end{array}$ \\
\hline $\begin{array}{c}\text { Yellow } \\
\text {," } \\
\text { Brown } \\
\text {," }\end{array}$ & $\begin{array}{c}\text { o0300 } \\
, " \\
00345 \\
00000 \\
,,\end{array}$ & $\begin{array}{l}6^{3} \\
6^{4} \\
6^{2} \\
6^{2} \\
6^{2}\end{array}$ & $\begin{array}{l}6^{3} \\
5^{4} \\
7^{2} \\
6^{2} \\
5^{2}\end{array}$ & $\begin{array}{l}6^{4} \\
6^{4} \\
6^{4} \\
6^{2} \\
5^{4}\end{array}$ & $\begin{array}{l}5^{4} \\
5^{4} \\
5^{4} \\
6^{3} \\
5^{4}\end{array}$ & $\begin{array}{c}5^{4} \\
5^{4} \\
6^{4} \\
4^{4}\end{array}$ & $\begin{array}{l}5^{4} \\
4^{4} \\
5^{4} \\
4^{4}\end{array}$ \\
\hline , & ", & - & $9^{2}$ & $7^{3}$ & $7^{3}$ & $7^{4}$ & $7^{4}$ \\
\hline Yellow & 00300 & - & $10^{4}$ & $13^{4}$ & II $^{4}$ & II $^{4}$ & $\mathrm{II}^{4}$ \\
\hline ," & 00000 & $\mathrm{II}^{4}$ & $10^{4}$ & $9^{4}$ & $9^{4}$ & $10^{4}$ & $10^{4}$ \\
\hline Brown & ", & $12^{4}$ & $12^{4}$ & - & - & - & - \\
\hline ", & $\begin{array}{l}\text {, } \\
\text { " }\end{array}$ & $\begin{array}{l}13^{2} \\
13^{2}\end{array}$ & $\begin{array}{l}\mathrm{IO}^{2} \\
\mathrm{II}^{2}\end{array}$ & $\begin{array}{r}9^{4} \\
10^{2}\end{array}$ & $\begin{array}{r}\mathrm{II}^{4} \\
9^{2}\end{array}$ & $\begin{array}{l}10^{4} \\
11^{2}\end{array}$ & $\begin{array}{l}10^{4} \\
12^{3}\end{array}$ \\
\hline Yellow & (12) 345 & - & $14^{4}$ & $11^{4}$ & $13^{4}$ & $16^{4}$ & $16^{4}$ \\
\hline , & , & - & $15^{4}$ & $15^{4}$ & $14^{4}$ & $16^{4}$ & $16^{4}$ \\
\hline , & I 2345 & $16^{4}$ & $14^{4}$ & - & - & - & - \\
\hline
\end{tabular}

The indices show the size of each animal at scoring, on the scale $\mathrm{I}=$ quarter-grown $\quad 2=$ half-grown $\quad 3=$ three-quarter-grown $4=$ adult 
It will be seen from the tables that there is a strong tendency for individuals from colonies with a low percentage of yellow shells to be darker than those from populations with a high one. In fact, on darker backgrounds there are fewer yellow shells, and fewer light-bodied individuals.

Microscopical examination shows that the colour of the body is due almost entirely to cells containing pigment granules. Most of these cells lie just below the epidermis and are typical melanophores, being branched, and crowded with minute granules of approximately uniform size. Others lie deeper in the body wall, are less branched, and contain large aggregations of pigments (plate I). In dark-bodied animals the melanophores are abundant and full of black ordark brown granules. In pale-bodied animals there are very few cells with pigment, and the pigment itself may be a pale red-brown. The granules are argentaffine, and bleach easily with bromine and hydrogen peroxide. They dissolve slowly in concentrated sodium hydroxide solution, not at all in acids. The pigment is therefore a melanin (Lison, I936, p. 249).

The results of the lighting experiment described under 'environmental effects' are shown in table 4. There is neither a systematic darkening nor lightening with increasing age, nor a change towards uniformity of body shade. There is some variation in the scores, especially those of the lighter individuals. This is due almost entirely to different attitudes of the buccal mass, and slight contractions of the body, which have most effect in the lighter individuals. The maximum variation so produced is 4 units in the very light snails (range 9-18) and decreases with increasing darkness, being 3 for range $3-6$.

\section{DISCUSSION}

\section{Correlation between body shade, shell colour, and background}

A comparison of sections taken from snails previously scored for body shade shows that the scores are good indicators of the degree of pigmentation and can be used to represent it in a statistical analysis (plate I). If the body shade is affected directly by the genes controlling shell pattern and colour, then there will of necessity be a correlation between these three variables, all of which must be considered in the analysis. Shell colour $(x)$ was scored as either yellow (I) or not yellow ( 0 ) ; body shade $(y)$ was scored on the scale of neutral shades $(0-20)$, and the number of bands $(z)$ was recorded (o-5). Then a regression between stations of body shade or shell colour is equivalent to a weighted regression on the proportion of yellows. An analysis of variance and covariance of $y$ on $x$ and $z$ was carried out.

When variation within stations totalled over all localities was considered, it was found that the bivariate regression on $x$ and $z$ was just significant at the 5 per cent level.

$$
y=\bar{y}+0 \cdot 263(x-\bar{x})-0 \cdot 140(z-\bar{z})
$$


There was no significant difference between the regressions calculated separately for each site. Neither of the single-variate regressions on $x$ and $z$ was significant.

The regression of $y$ on $x$ between stations (fig. I) was highly significant $\left(P<\mathrm{O}^{\circ} \mathrm{OI}\right)$. The inclusion of $z$ in the regression did not reduce the residual sum of squares significantly. The mean square corresponding to deviations from the regression between stations is significantly greater than that for the regression within stations. This suggests that some additional factor dependent on locality is operating, and the suggestion is confirmed by the fact that the two regressions differ significantly.

As there was a large variation in the proportions of yellow shells (ranging from o to 0.93 ), they were transformed to angles, and a weighted correlation coefficient between angle and mean body shade for the nineteen stations was calculated. The value obtained was 0.63 , which with $\mathrm{I} 7$ degrees of freedom is significant at the I per cent level.

Consequently, there is some suggestion that the possession of a particular shell colour and pattern does affect the body shade of the individual. Snails with yellow and unbanded shells may have a tendency to lighter body colour. But this effect is insufficient to account for the strong connexion between a high percentage of yellow shells and a pale average body colour in the same colony, and conversely a low percentage of yellow shells and a dark average body colour.

Inspection of the collecting stations shows that the browner the backgrounds, the darker they are in shade. In the dense beechwoods, where there is little or no green undergrowth, the background is made up of red-brown leaves, dark brown twigs, cupules, and other litter, and exposures of dark soil. In the greener hedgerows and rough places, on the other hand, there is much pale leaf-litter, dry grass stems, and green grass, all of which form a background much lighter in shade than that of the beechwoods. It has been shown already (Cain and Sheppard, 1950) that the percentage of yellow shells in a colony is correlated with the greenness of the background. There is therefore also a correlation between the percentage of yellow shells and the lightness of the background.

\section{Explanation of the correlation}

There are four possible explanations of the correlation between light body-shade and high percentage of yellow shells in a colony:

(i) Individual animals may be able to change colour to harmonise with the background.

(ii) The food available may be different in different localities and may affect body shade.

(iii) The greener localities are less shaded than the dark ones, and the bodies of snails in greener areas may become bleached to some extent.

(iv) Body shade may be primarily genetically determined, and 
subject to predatory selection of the same nature as that already shown to act on the shells.

The hypothesis of colour change in these animals is wholly unsupported by evidence; no such change has ever been reported, and contraction of pigment within the melanophores has not been observed. Moreover, the animals which were kept together under the same conditions showed no tendency to assume even approximately the same shade (table 4). Food is unlikely to affect melanin formation to the necessary degree. The animals kept together, although fed on the same diet, showed no disposition towards similarity. The same experiment gives no support for the hypothesis of bleaching. The container was shaded, and bleaching greatly reduced, if not wholly prevented. If lighter body colour in more exposed situations were due entirely to bleaching, then young animals taken from such situations and protected should become nearly as dark as the darkest adults found.

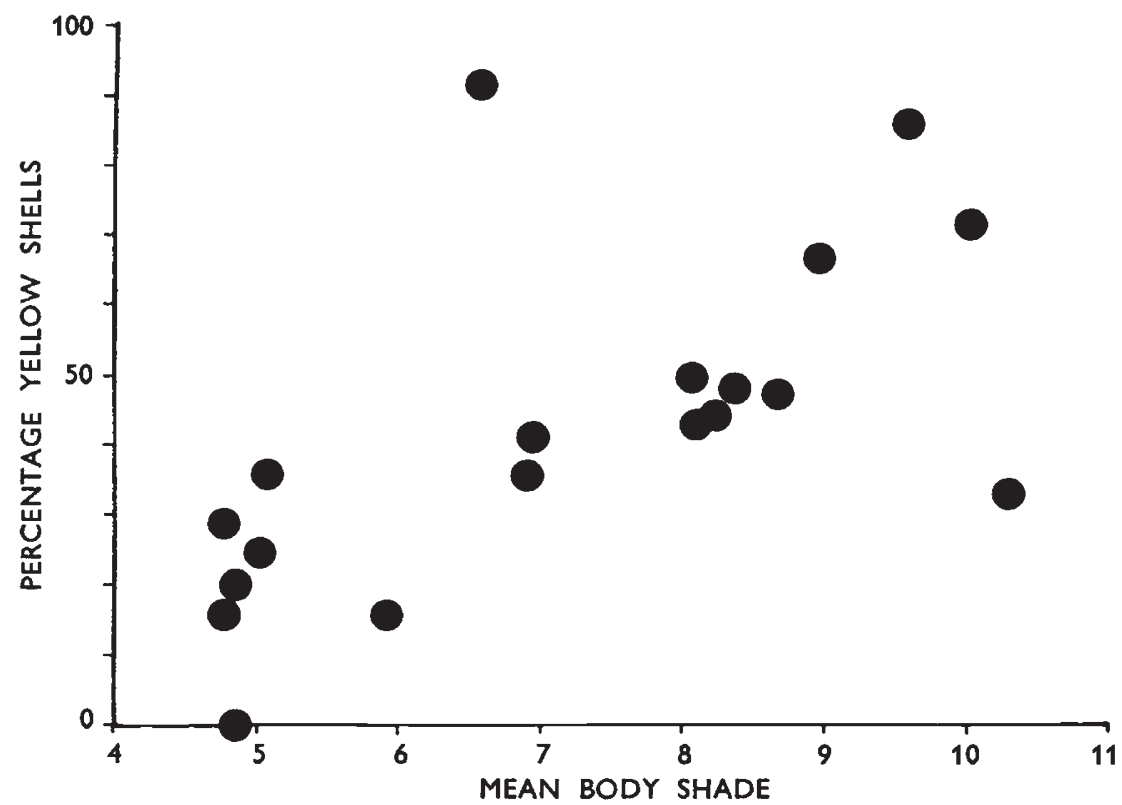

FIG. I.-Correlation between mean body shade and percentage of yellow shells in each locality. $(\mathrm{P}<0.0 \mathrm{I})$. For discussion of the two divergent colonies see page 228 .

If some of the paleness of juveniles were due to youth only, again they should darken with age. The experiment gives no indication of a general increase in darkness. Furthermore, juveniles collected in beech woods are generally very dark, some as dark as the darkest adults. There is no evidence of any extensive change of body shade with age.

It appears therefore that differences in body shade are primarily genetically determined. This hypothesis is supported by the relative stability of colour with age, and is further upheld by the significance of the bivariate regression of body colour on shell colour and banding, which shows that genes do affect body shade. The range of variation 
within each colony indicates that, as might be expected, the control is multifactorial.

Both shell colour and body shade, therefore, are genetically determined. But the genetic effect of shell colour and banding on body shade is not sufficient to account for the correlation between mean body shade and the percentage of yellow shells within each colony. The factor dependent on locality which is producing this correlation can only be natural selection by predators, favouring light body shade on light backgrounds and dark shade on dark ones.

Fig. I shows the correlation between mean body shade and percentage of yellow shells in the localities examined. Two stations are somewhat divergent. The colony at Stretham has a high percentage of yellow shells but a dark mean body shade; that in Marley Wood, on the contrary, has a light mean shade for the percentage of yellow shells. At Stretham there was a long ditch with much dark soil, associated with very fresh green herbage, which may possibly account for this combination of values. Marley Wood is exceptional among the localities studied because of the great quantity of dead bracken fronds and other light brown litter there. The background is therefore predominantly light brown during much of the year, and the colony living on it has a light mean body shade and a high proportion of fawn, not yellow, shells.

\section{The relationship between mean body shade and mean shell shade in the pink class}

The shells that are not yellow are either brown or one of a series of shades collectively described as pink because of the characteristic ground-colour of the shell. This series is continuous and has been divided for scoring into four groups, light fawn, fawn, pink and red. (In our previous paper-Cain and Sheppard, I950-the first two were combined as fawn.) If natural selection is acting on the body shade, it might be expected to act even more intensely on the shade of the shell, which is more frequently exposed. Within the pink series the lighter shades should be selected for on the lighter backgrounds. Therefore one would expect a correlation between mean shell shade (within the pink class) and mean body shade.

The same type of statistical analysis as used above was carried out, body shade being scored as before (0-20) and shell shade as $0-3$ in order of increasing darkness, which is also the order of increasing redness. There is a highly significant correlation (fig. 2) between mean body shade and mean shell shade $(\mathrm{P}<0.00 \mathrm{I})$, as expected. Moreover, there is no significant regression whatever of body shade on shell shade within colonies, so that again there is no single direct genetic connexion between the two. It has been shown (see Cain and Sheppard, 1950) that shell colour is not influenced by food. Fading is not in question here, since faded shells can be recognised as such, and included in the correct class. The shade of shell colour, therefore, 
is also genetic and probably multifactorial. Moreover, because there is no correlation between body shade and shell shade in each individual, it is obvious that paleness cannot be due to fading in both.

Since there is a correlation between percentage of yellow shells within a colony and mean body shade, and between mean body shade and mean shade of pink, the possibility arises that yellow is incompletely recessive and that the paleness of the pinks in colonies with high percentages of yellows is due to a preponderance of heterozygous

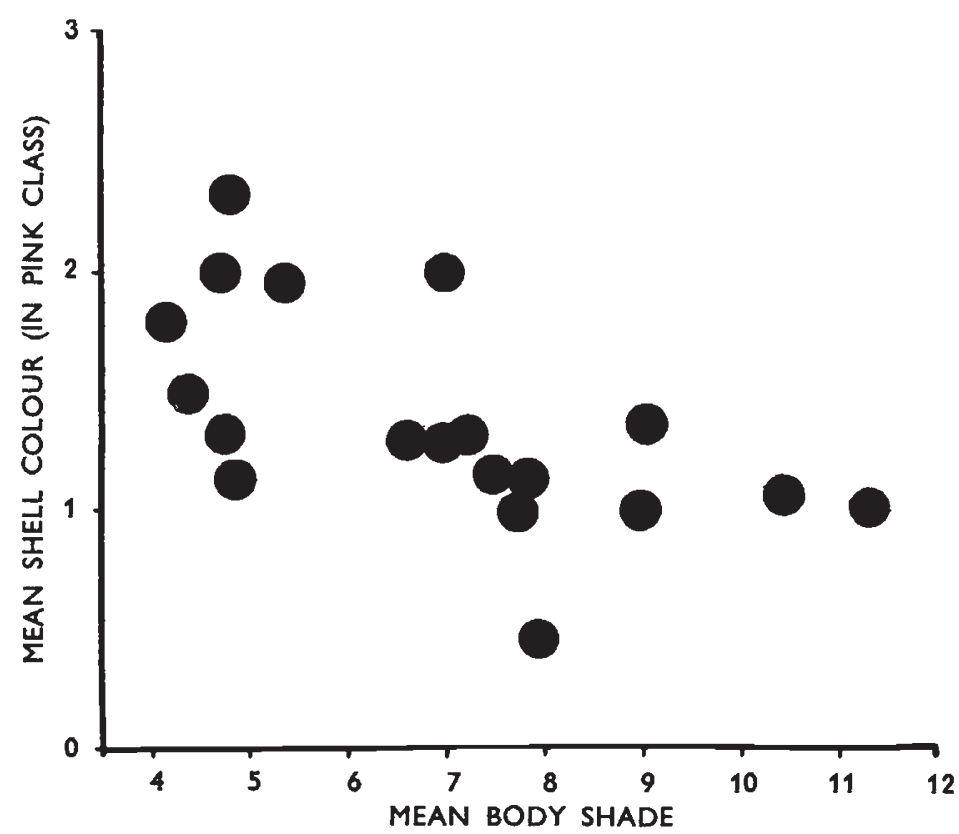

Fig. 2.-Correlation between mean body shade and mean shell shade within the pink class. (P<O•oor.)

pinks. But this hypothesis does not fit the facts. Of the colonies already described (Cain and Sheppard, 1950, table 2), Putall Gate has a very low percentage of yellows $(3 \cdot 6)$ but a high proportion of the paler pinks, giving a pale mean shade of pink for the colony. Rockley, on the other hand, with a much higher percentage of yellows $(27.5)$ has a higher proportion of the two darker classes. Other colonies show similar discrepancies.

The importance of natural selection in controlling variation

It appears, therefore, that the mean body shade, the mean shade of shell colour within the pink series, and the proportions of yellow and highly banded shells are all controlled by natural selection, not merely within a colony, but within different parts of a colony when there is variation in the background. Preliminary observation shows that the exact shade of brown also varies with the lightness of the background. 
Sheppard (in press) has shown very striking variations in the proportions of varieties at Rockley over a distance of less than roo yards. The correspondence of geographical variation in the colony and in the background is remarkable. Lamotte (I95I) considers that breeding communities of Cepaea of radius less than 30 metres are panmictic. If so, then selection must be heavy to produce this correspondence.

In this species, then, we have major genes controlling colour and banding, and minor ones affecting shell and body shade; and both are controlled by selection. There are grounds for believing that the selection must be intense. It seems that whenever selection coefficients, even of apparently trivial characters, are adequately investigated, they are found to be surprisingly high (Mayr and Stresemann, 1950). Since conditions are never constant in nature, fluctuations in selection values are likely to be the rule, and will produce consequences identical with those ascribed to genetic drift (Sewall Wright, I940, I948) but not restricted by the size of the colony. It appears that natural selection is by far the most important agent in respect to all those characters that can be distinguished at all.

\section{SUMMARY}

I. In Cepaea nemoralis a high correlation was found between the percentage of yellow shells in a colony and the mean body shade in that colony, but hardly any between the shell colour and body shade in each individual. Animals with ycllow unbanded shells tend to have paler bodies, but this effect is wholly insufficient to account for the general correlation between mean body shade and the percentage of yellow shells.

2. Body shade appears to be a genetic character, multifactorially controlled and unaffected by the environment.

3. The correlation of mean body shade with percentage of yellow shells is observed to be also a correlation with the general lightness or darkness of the background, and is the result of natural selection by visual predators.

4. This conclusion is confirmed by observation of the mean shade of shells in the pink class. The control of shell colour within this class is also multifactorial and highly correlated with the mean body shade in each colony, although not in each individual.

5. Natural selection, therefore, controls the frequency, not only of the major genes for colour and banding, but also of the numerous modifiers influencing the shade of the body, of the pink shells, and probably also of the brown shells.

Acknowledgments.-We are deeply indebted to Dr M. R. Sampford for the statistical analysis, and to Professor R. A. Fisher and Dr E. B. Ford, both of whom read this paper in manuscript. Grateful acknowledgment is made to the Department of Scientific and Industrial Research for a grant received by one of us (P. M. Sheppard). We are grateful to Mr P. L. Small for the photographs in plate $\mathbf{I}$. 

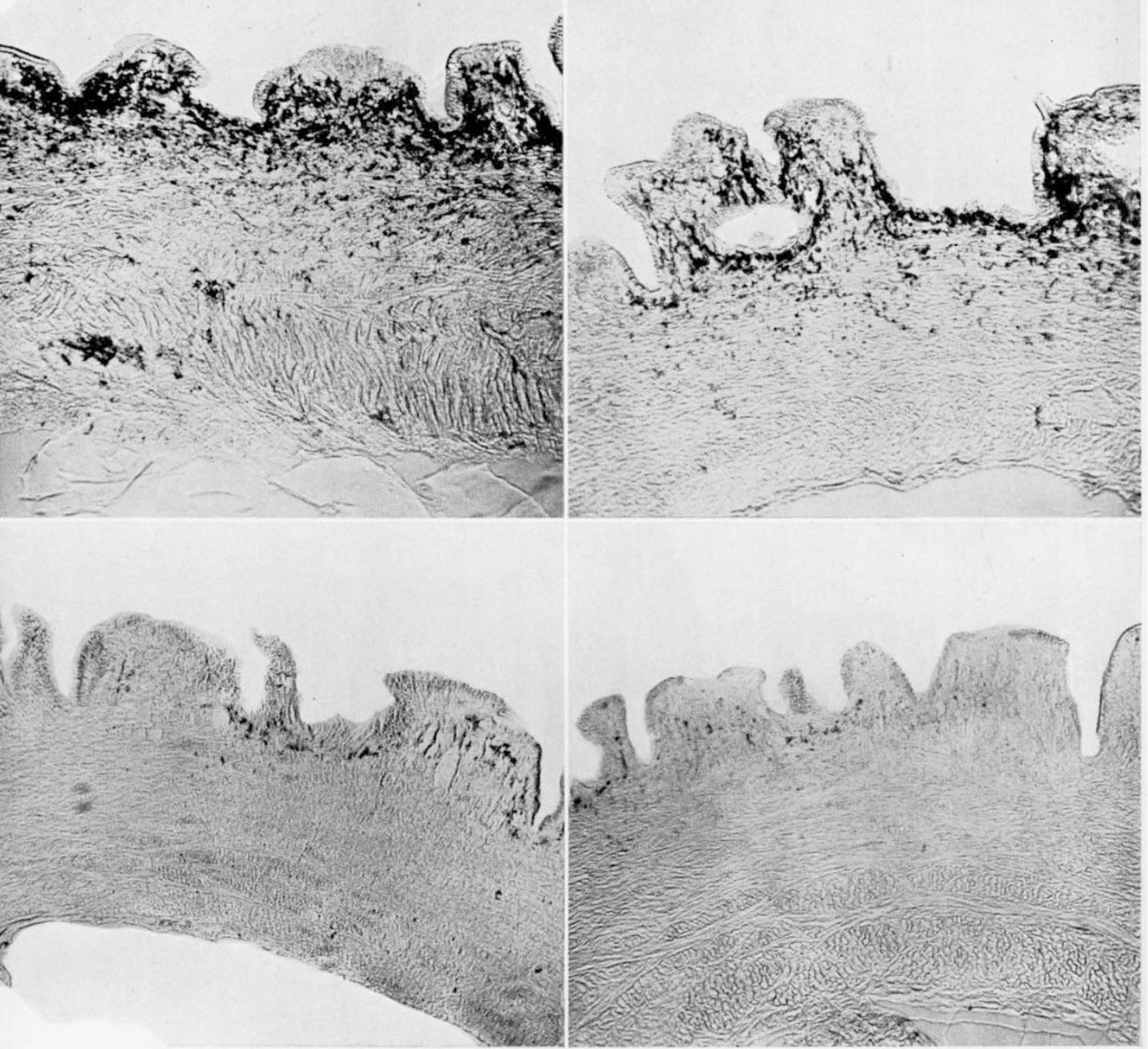

Plate I.-Unstained transverse sections taken immediately behind the tentacles, showing degree of pigmentation. Body shade, previously determined, was 4,7 , no and 13 in figs. $a, b, c$ and $d$ respectively. All figures $\times 80$. 


\section{REFERENCES}

BAKER, J. R. 1944. The structure and chemical composition of the Golgi element. Quart. F. Micr. Sci., 85, 1-71.

CAin, A. J., AND Sheppard, P. M. 1950. Selection in the polymorphic land snail Cepaea nemoralis. Heredity, 4, 275-294.

LAмотте, м. 1950. Observations sur la sélection par les prédateurs chez Cepaea nemoralis. F. de Conchyliologie, 9o, $180-190$.

LAмотTE, M. 1951. Recherches sur la structure génétique des populations naturelles de Cepaea nemoralis. Ann. Biol., 27, 39-49.

LISON, L. 1936. Histochimie animale, méthodes et problèmes. Paris, Gauthier-Villars. maYr, E., AND stresemann, E. 1950. Polymorphism in the chat genus Oenanthe (Aves). Evolution, 4, 291-300.

SHEPPARD, P. M. 1951. Fluctuations in the selective value of certain phenotypes in the polymorphic land snail Cepaea nemoralis (L.). Heredity, 5, 125-134.

villalobos, c. AND J. 1947. Colour Atlas. Buenos Aires, El Ateneo.

WRIGHT, s. 1940. The statistical consequences of Mendelian heredity in relation to speciation. In The New Systematics, ed. Huxley. London, O.U.P.

WRIGHT, s. 1948. On the roles of directed and random change in gene frequency in the genetics of populations. Evolution, 2, 279-294. 